\title{
Model Economic Production Quantity (EPQ) dengan Sinkronisasi Demand Kontinu Dan Demand Diskrit pada Produksi Kerupuk Ikan Sungai Khas Kalimantan Timur
}

\author{
Etwin Fibrianie $^{1^{*}}$, Dwi Cahyadi ${ }^{2}$, Andi Farid $\mathbf{H}^{3}$ \\ Politeknik Negeri Samarinda, Jl. Dr.Ciptomangunkusumo Kampus Gn.Lipan Samarinda \\ *E-mail: etwin.f@gmail.com
}

\begin{abstract}
Economic Production Quality (EPQ) model's directs the company to minimize total cost production by reducing inventory cost. The basic model parameters of EPQ are demand, machine setup cost and inventory store cost. But in fact the company not only has a continuous demand, but sometimes the discrete demand that fulfillment is done within a certain time range. UD. Sanda as a producer of East Kalimantan typical fish crackers. In the fulfillment of consumer needs consists of 2 types of demand. This research uses quantitative method. From the review of the number of requests and calculations to the inventory level, the optimal cycle time is two times and the average cost is Rp. 3.336.750, -/period, total cost is Rp. 6.673.500,-
\end{abstract}

Keywords: EPQ, demand continous, demand descrete, inventory, fishcrackers, Kalimantan Timur

\begin{abstract}
ABSTRAK
Model Economic Production Quality (EPQ) mengarahkan perusahaan agar dapat meminimalkan total biaya produksi dengan mereduksi biaya inventori. Parameter model dasar EPQ adalah demand, biaya setup mesin dan biaya simpan persediaan. Namun dalam kenyataanya perusahaan tidak hanya memiliki demand yang bersifat kontinu, namun sering kali terjadi demand diskrit yang pemenuhannya dilakukan dalam suatu rentang waktu tertentu. Begitu pula halnya dengan UD. Sanda sebagai produsen kerupuk ikan khas Kalimantan Timur, dalam pemenuhan kebutuhan konsumen terdiri dari 2 tipe demand. Penelitian ini menggunakan metode kuantitatif. Dari peninjauan jumlah permintaan dan perhitungan terhadap tingkat persediaan, diperoleh waktu siklus pengiriman optimal adalah 2 kali dan biaya rata-rata satu periode adalah Rp. 3.336.750,- serta biaya total sebesar Rp. 6.673.500,-
\end{abstract}

Kata kunci: EPQ, demand kontinu, demand diskrit, persediaan, kerupuk ikan, Kalimantan Timur

\section{PENDAHULUAN}

Proses juga diartikan sebagai cara, metode ataupun teknik bagaimana produksi itu dilaksanakan. Produksi adalah kegiatan untuk menciptakan dana menambah kegunaan (Utility) suatu barang dan jasa. Proses produksi adalah suatu cara, metode ataupun teknik menambah keguanaan suatu barang dan jasa dengan menggunakan faktor produksi yang ada[24].

Perencanaan produksi adalah langkah yang sangat penting [1] karena merupakan proses menerjemahkan strategi dan tujuan perusahaan kedalam kegiatan produksi [12], salah satu prosesnya yaitu menentukan berapa ukuran lot produksi perusahaan. Bahan baku merupakan hal paling utama yang harus ada didalam perusahaan, terutama perusahaan industri, karena bahan baku merupakan bagian dari suatu proses produksi yang harus ada didalam perusahaan dan tidak dapat diabaikan keberadaannya, baik dalam kuantitas maupun kualitas yang telah ditentukan oleh perusahaan [8].

Model persediaan yang paling banyak digunakan dalam menentukan ukuran lot produksi adalah Economic Production Quantity (EPQ) [9]. Tingkat produksi optimal atau Economic Production Quantity (EPQ) adalah sejumlah produksi tertentu yang dihasilkan dengan meminimumkan total biaya persediaan [18]. Metode Economic Order Quantity didalam menentukan kuantitas pembelian bahan baku pembantu yang optimal, sehingga dapat meminimalkan total biaya yang dikeluarkan oleh perusahaan setiap tahunnya [3].

Pengembangan model EPQ yang begitu luas mencakup kondisi produk multi-item, adanya kebijakan backorder, berkaitan dengan produk yang terdeteriorasi, adanya produk cacat, hingga kegiatan rework. Metode EPQ juga memiliki banyak keterbatasan dan 
kondisi-kondisi yang harus dipenuhi, misalnya tentang perubahan harga yang kemungkinan terjadi, maka hendaknya perusahaan juga memperhatikan faktor perubahan harga dalam menentukan pembelian persediaan bahan baku [3].

Model EPQ klasik menjabarkan kegiatan produksi dilakukan dalam memenuhi demand produk yang pemenuhan ke konsumennya dilakukan setiap saat per satuan waktu.Algoritma genetika merupakan salah satu algoritma yang sangat tepat digunakan untuk penyelesaian masalah optimasi yang kompleks dan sukar diselesaikan dengan menggunakan metode yang konvensional. Algoritma ini mempunyai fleksibilitas untuk dapat diimplementasikan secara efisien pada problematika tertentu, dan bersifat mencari kemungkinan- kemungkinan untuk mendapatkan suatu solusi yang optimal bagi penyelesaian masalah dari kandidat solusi [33].

Pada situasi real di lapangan banyak kondisi-kondisi yang menyebabkan sebuah perusahaan tidak dapat menerapkan model ini. Salah satunya adalah situasi dimana perusahaan juga memiliki demand diskrit [18], yaitu demand yang dipenuhi dalam setiap rentang waktu tertentu. Ketika perusahaan juga memiliki tipe demand diskrit, maka sebagian hasil produksi akan tersimpan lebih lama di gudang dan meningkatkan biaya simpan produk. Hal ini dikarenakan sifat dari demand diskrit yang menyebabkan waktu pengiriman dapat terjadi sewaktu-waktu, tidak sesuai yang jadwalkan.

Yang menjadi perhatian bagi perusahaan adalah kuantitas pembelian dan ketidakpastian permintaan yang berasal dari luar perusahaan. Apabila ketidakpastian ini tidak diantisipasi dapat berakibat perusahaan sering mengalami stockout dan akan menimbulkan biaya kekurangan persediaan (stockout cost) yang cukup besar [23].Untuk mengantisipasi ketidakpastian penggunaan bahan yang berasal dari dalam perusahaan, dapat dilakukan dengan membuat persediaan pengamanan (safety stock). Persediaan pengaman ditentukan tidak terlalu besar dan juga tidak terlalu kecil. Dengan kata lain perlu ditentukan jumlah persediaan pengaman yang optimum, yaitu persediaan yang menimbulkan biaya persediaan minimum [15].

UD. Sanda merupakan salah satu usaha kecil di daerah Kota Bangun yang bergerak di bidang produksi kerupuk ikan sungai khas Kalimantan Timur. Dalam produksinya UD Sanda, memproduksi kerupuk pasca terjadinya banjir besar, hal tersebut dikarenakan pasca banjir kapasitas ikan yang diperoleh melimpah. Kondisi alam yang berubah menyebabkan tidak dapat di prediksi kapan terjadi banjir. UD Sanda pun dalam menyediakan kerupuk ke pelanggan tidak menghitung secara pasti berapa keperluan yang harus disediakan, berapa produk yang harus dikirim ke pelanggan setiap periodenya. Berdasar latar belakang diatas maka akan di formulasikan berapa siklus pengiriman optimal dan berapa besar biaya pengiriman per periodenya.

\section{METODOLOGI}

Metodologi penelitian menjelaskan langkah-langkah yang dilakukan dalam melaksanakan sebuah penelitian. Penelitian ini menggunkan metode kuantitatif dengan didahului oleh studi literature. Penelitian ini pun bersifat aplikatif terhadap rumus yang ada dan disesuaikan dengan kondisi di lapangan. Terkait dengan penelitian yang akan dilakukan, berikut merupakan tahapan-tahapan dari penelitian tersebut.

\section{Literature Review}

Dimulai dengan melakukan riset tentang perkembangan model Economic Production Quantity (EPQ) yang dilakukan dengan me-review jurnal-jurnal penelitian terdahulu yang dirangkum dalam Tabel 1 . Hal ini dilakukan untuk mencari penelitian yang dapat mendukung dan menentukan apakah penelitian yang akan diangkat saat ini pernah dilakukan sebelumnya atau tidak. Hingga akhirnya diperoleh posisi penelitian yang akan akan dikembangkan saat ini.

Tabel 1 Literature Review

\begin{tabular}{lll}
\hline NO & Nama & Pembahasan \\
\hline 1 & 17 & $\begin{array}{l}\text { Dengan EPQ perusahaan bahan baku daging } \\
\text { menghasilkan Total Cost lebih murah di } \\
\text { banding dengan kebijakan perusahaan }\end{array}$ \\
\hline 2 & 18 & $\begin{array}{l}\text { Hasil dari algoritma genetika dapat } \\
\text { meminumkan EPQ diperoleh hasil total cost } \\
\text { lebih kecil dari biasanya }\end{array}$ \\
\hline 3 & 16 & $\begin{array}{l}\text { EPQ menghasilkan efisiensi bahan baku } \\
\text { tepung }\end{array}$ \\
\hline 4 & 20 & $\begin{array}{l}\text { Solusi optimal dihitung menggunakan } \\
\text { model optimisasi ukuran lot produksi pada } \\
\text { sistem tidak sempurna (deteriorasi) dengan } \\
\text { mempertimbangkan inspeksi sampling } \\
\text { berganda. }\end{array}$ \\
\hline
\end{tabular}




\begin{tabular}{|c|c|c|}
\hline \multicolumn{3}{|c|}{ JURNAL SAINS TERAPAN VOL. 4 NO. 1, APRIL 2018} \\
\hline 5 & 2 & $\begin{array}{l}\text { Dengan menjumlahkan pembelian barang } \\
\text { dagangan yang ekonomis (EPQ) dengan } \\
\text { persediaan pengaman, maka dapat diketahui } \\
\text { persediaan maksimum yang harus } \\
\text { dipertahankan oleh perusahaan. }\end{array}$ \\
\hline 6 & 24 & $\begin{array}{l}\text { Penerapan metode EPQ pada perusahaan } \\
\text { menghasilkan biaya yang lebih murah jika } \\
\text { dibandingkan dengan metode yang selama } \\
\text { ini diterapkan olehperusahaan. }\end{array}$ \\
\hline 7 & 32 & $\begin{array}{l}\text { Upaya pengrajin kecil mempromosikan } \\
\text { produknya melalui IT dan perlu } \\
\text { pengembangan dan dukungan pemerintah } \\
\text { agar IKM terus maju }\end{array}$ \\
\hline 8 & 4 & $\begin{array}{l}\text { Model yang dihasilkan merupakan model } \\
\text { optimisasi dalam penentuan ukuran lot } \\
\text { produksipada setiap run ke - i yang } \\
\text { mempertimbangkan inspeksi terhadap } \\
\text { sampel yang diambil } \\
\text { dari lot yang dihasilkan dengan kriteria } \\
\text { minimisasi total ongkos }\end{array}$ \\
\hline 9 & 27 & $\begin{array}{l}\text { Ketika demand lebih kecil daripada } \\
\text { kapasitas, maka total ongkos yang } \\
\text { dihasilkan merupakan total ongkos yang } \\
\text { paling minimum dibandingkan dengan } \\
\text { demand lebih besar daripada kapasitas dan } \\
\text { demand sama dengan kapasitas. }\end{array}$ \\
\hline 10 & 13 & $\begin{array}{l}\text { Variabel upah berpengaruh negatif dan } \\
\text { tidak signifikan terhadap penyerapan tenaga } \\
\text { kerja, variabel produktivitas berpengaruh } \\
\text { negatif dan signifikan terhadap penyerapan } \\
\text { tenaga kerja dan variabel modal kerja } \\
\text { berpengaruh positif dan signifikan terhadap } \\
\text { penyerapan tenaga kerja pada industri kecil } \\
\text { ikan asin. }\end{array}$ \\
\hline 11 & 31 & $\begin{array}{l}\text { Persediaan cukup optimal karena hanya } \\
\text { kurang sekitar } 30 \% \text { dari EPQ pada } \\
\text { dagangan beras }\end{array}$ \\
\hline 12 & 35 & $\begin{array}{l}\text { Dengan menggunakan rumus } \\
\text { Economic Order Quantity (EPQ) terjadi ih } \\
\text { sedikit dari biasanya sehingga dapat kan } \\
\text { biaya persediaan }\end{array}$ \\
\hline 13 & 29 & $\begin{array}{l}\text { Bahwa pengadaan solar OQ menghasilkan } \\
\text { titik pengiriman dan biaya minimal }\end{array}$ \\
\hline 14 & 23 & $\begin{array}{l}\text { Formulasi model bertujuan untuk } \\
\text { merumuskan model matematis dalam } \\
\text { menghitung waktu siklus produksi yang } \\
\text { optimal. }\end{array}$ \\
\hline 15 & 10 & $\begin{array}{l}\text { Model Economic OrderQuantity didapatkan } \\
\text { hasil bahwa pemesananbahan baku yang } \\
\text { optimal untuk PT. NewMakmurtex } \\
\text { sebanyak } 43.195,372 \mathrm{~m} \text {, }\end{array}$ \\
\hline 16 & 19 & $\begin{array}{l}\text { Perhitungan persediaan bahan baku lebih } \\
\text { optimal jika menggunakan EPQ }\end{array}$ \\
\hline 17 & 11 & $\begin{array}{l}\text { JIT malah akan merugikan perusahaan } \\
\text { karena tidak adanya usahauntuk } \\
\text { mengurangi persediaannya. Lebih baik } \\
\text { menggunakan EPQ }\end{array}$ \\
\hline 18 & 20 & $\begin{array}{l}\text { Persediaanmaksimum (Maximum } \\
\text { inventory) yangharus disediakan perusahaan } \\
\text { meurut metode EPQ adalah sebesar } 4,688 \\
\mathrm{~m}^{3} \text {, sedangkanmenurut kebijakan } \\
\text { perusahaan tidak adapersediaan maksimum } \\
\text { yang disediakanperusahaan }\end{array}$ \\
\hline 19 & 28 & $\begin{array}{l}\text { Dari hasil perhitungan dengan } \\
\text { menggunakan metode EPQ, UD Nabila } \\
\text { dapat mengetahui jumlah pembelian bahan } \\
\text { bakuoptimal yang harus disediakan } \\
\text { sehingga UD Nabila tidak terjadi } \\
\text { emborosan biaya dan tidakterjadi } \\
\text { kekurangan bahan baku. }\end{array}$ \\
\hline
\end{tabular}

\begin{tabular}{|c|c|c|}
\hline 20 & 21 & $\begin{array}{l}\text { Economic ProductionQuantity dapat } \\
\text { dikembangkan denganmenambahkan } \\
\text { komponen biaya antar barang.Pdaa artikel } \\
\text { ini telah diperoleh masalhoptimasi berupa } \\
\text { meminimuman Fungsi biayayang diperoleh } \\
\text { dari total jumlahan biayapersiapan, biaya } \\
\text { produksi, biaya perawatandan biaya } \\
\text { transportasi. Dari formulasi modeltersebut } \\
\text { dapat ditentukan kapan perusahaanharus } \\
\text { memulai produksi, berapa banyakbarang } \\
\text { yang harus diproduksi dalam satusiklus } \\
\text { produksi, berapa besar kapasitas paletuntuk } \\
\text { satu kali pengiriman dan berapabanyak } \\
\text { jumlah angkutan terbaik yang harusdimiliki } \\
\text { oleh perusahaan. }\end{array}$ \\
\hline 21 & 14 & $\begin{array}{l}\text { Nilai ukuran kuantitas produksi optimal dan } \\
\text { total cost yang diperoleh dengan } \\
\text { menggunakan metode Economic Production } \\
\text { Quantity (EPQ) adalah sebesar } 43.657 \text { unit } \\
\text { perbulan, sedangkan untuk total cost-nya } \\
\text { adalah Rp } 7.176 .177,3 \text { perbulan.sedangkan } \\
\text { Nilai ukuran kuantitas produksi optimal dan } \\
\text { total cost yang diperoleh dengan } \\
\text { menggunakan metode Economic Order } \\
\text { Quantity (EPQ) adalah sebesar } 40.870 \text { unit } \\
\text { perbulan, sedangkan untuk total cost -nya } \\
\text { adalah Rp } 6.416 .596,4 \text { perbulan. }\end{array}$ \\
\hline 22 & 5 & $\begin{array}{l}\text { Model EPQ dengan modifkasi } 3 \text { item yakni } \\
\text { shortages, time varying demand and } \\
\text { Entropy cost. }\end{array}$ \\
\hline 23 & 30 & $\begin{array}{l}\text { Persediaan bahan baku menggunakan } \\
\text { metode harga rata - rata dimana baik harga } \\
\text { kontrak dan non kontrak dimasukkan dalam } \\
\text { proses produksi maupun persediaan akhir. }\end{array}$ \\
\hline 24 & 22 & $\begin{array}{l}\text { Model Economic Production Quantity } \\
\text { model dengan pengiriman produk by } \\
\text { multiple palet system and with } \\
\text { transportation cost. }\end{array}$ \\
\hline 25 & 7 & $\begin{array}{l}\text { Literatur review terhadap seluruh model epq } \\
\text { yang ada dengan parameter yang berbeda, } \\
\text { kemudian di cari gap penelitiannya. }\end{array}$ \\
\hline
\end{tabular}

\section{Identifikasi dan Rumusan Masalah}

Identifikasi masalah bertujuan untuk menentukan masalah apa yang akan diselesaikan dalam penelitian, kemudian permasalahan tersebut dirumuskan sehingga menjadi jelas aspek yang akan diteliti.

\section{Formulasi Model}

Formulasi model EPQ dilakukan dengan mempertimbangakn dua tipe demand, yaitu kontinu dan diskrit secara simultan untuk menentukan waktu siklus optimal $T$. Penentuan solusi optimal akan dilakukan dengan pendekatan aljabar, algoritma dan pendekatan simultan.

\section{Penutup}

Pada bagian penutup, hasil yang diperoleh pada penelitian ini dirangkum menjadi sebuah kesimpulan yang merujuk pada pencapaian tujuan dari penelitian dan saran yang berguna untuk pelaksanaan penelitian selanjutnya. 


\section{HASIL DAN PEMBAHASAN}

\section{Formulasi Model}

\section{Asumsi dan Notasi}

Dalam penelitian ini model EPQ yang digunakan adalah aplikasi daripada penelitian [24], yakni EPQ yang tersinkronisasi demandnya antara diskrit dan kontinu.

Model EPQ dikembangkan dengan mempertimbangkan dua tipe permintaan (demand), yaitu permintaan kontinu dan diskrit, sehingga inventory on-hand yang disimpan di gudang menjadi seperti yang terlihat pada Gambar 1 [23].

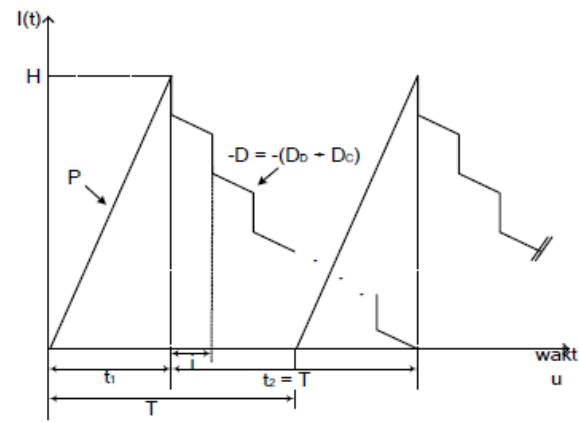

Gambar 1. Persediaan Model EPQ dengan Dua Tipe Demand [24]

Adapun asumsi dasar yang digunakan adalah:

1. Interval waktu pengiriman demand diskrit tetap

2. Komponen biaya tidak berubah sepanjang periode produksi

3. Harga produk tetap dan tidak terdapat diskon pembelian

4. Breakdown mesin tidak terjadi selama kegiatan produksi berlangsung

5. Tidak ada kondisi backorder dan rework

6. Deteriorasi mesin dan peralatan tidak terjadi selama kegiatan produksi

7. Kapasitas produksi dan pengiriman adalah tetap

8. Tidak terdapat imperfect product / produk cacat yang dihasilkan

9. Tidak ada safety stock

10. Selama waktu produksi, tidak ada kegiatan konsumsi produk. Demand pada siklus tersebut dipenuhi berdasarkan produksi siklus sebelumnya.

11. Produk yang diproduksi adalah single item product.
Notasi-notasi yang digunakan dalam model tersebut adalah:

\section{Variabel Keputusan}

$\mathrm{T}$ : panjang waktu siklus (waktu)

Parameter

$\mathrm{H}$ : persediaan maksimal ketika kegiatan produksi berakhir (unit)

t1 : lama waktu produksi pada satu siklus (waktu)

t2: waktu yang diperlukan untuk mengirimkan produk pada satu siklus (waktu)

Q : ukuran lot produksi (unit)

$\mathrm{I}(\mathrm{t})$ : jumlah persediaan pada waktu $t$ (unit)

$\mathrm{cp}$ : biaya produksi (Rp/unit)

cs : biaya set up mesin (Rp)

cf : biaya pengiriman tetap (Rp)

cd : biaya pengiriman variabel (Rp/unit)

$\mathrm{h}$ : biaya simpan (Rp/unit.waktu)

h1 : biaya simpan produk yang ditanggung konsumen (Rp/unit.waktu)

$\mathrm{D}$ : demand total (unit/waktu)

DD : demand diskrit (unit/ waktu)

DC : demand kontinu (unit/ waktu)

$\mathrm{p}$ : kapasitas produksi (unit/ waktu)

$\mathrm{n}$ : frekuensi pengiriman demand diskrit dalam satu siklus (bil. integer)

$\mathrm{TC}(\mathrm{T}, \mathrm{n})$ : biaya total per siklus $(\mathrm{Rp})$

$\mathrm{E}[\mathrm{TCU}(\mathrm{T}, \mathrm{n})]$ : biaya rata-rata satu periode produksi (Rp)

\section{Formulasi Matematis}

Kegiatan memproduksi produk akhir membutuhkan biaya produksi per unit produk $c p$ sebanyak ukuran lot produksi $Q$, maka biaya produksi dalam satu siklus adalah

Biaya produksi persiklus $=\boldsymbol{c p} . Q(1)$

Frekuensi replenishment produk dalam satu tahun diperoleh dengan membagi demand $\mathrm{D}$ dan ukuran lot produksi $\mathrm{Q}$, yaitu $1 / \mathrm{T}=\mathrm{D} / \mathrm{Q}$. Oleh karena itu, diperoleh bahwa $\mathrm{Q}=\mathrm{TD}$, sehingga biaya produksi dalam satu siklus menjadi

Biayaproduksipersiklus $=c p . T . D$

Sedangkan biaya set up mesin cs merupakan biaya yang diperlukan satu kali untuk proses produksi dalam setiap siklus.

Biayasetuppersiklus $=$ cs (3)

Biaya pengiriman produk dibagi menjadi dua, yaitu biaya tetap $c f$ per tiap pengiriman $\mathrm{n}$ untuk demand diskrit serta biaya variabel $c d$ per unit 
produk yang dikirim untuk kedua tipe demand, sehingga biaya total pengiriman produk dalam satu siklus adalah $B$. totalpengirimanprodukpersiklus

$$
=(n . c f)+(c d . T . D)
$$

Demand diskrit dikirim $\mathrm{n}$ kali dalam setiap siklus dengan interval pengiriman i, sedangkan demand kontinu dikirim setiap saat sepanjang t2. Gambar 2. menjelaskan bahwa:

$$
\boldsymbol{t 1}=\boldsymbol{Q P}=\boldsymbol{T D P}
$$

$$
H=T D
$$

maka,

$H D=Q=T D D$

$H C=Q=T D C$

Perhitungan biaya simpan dibagi menjadi 2, yaitu biaya simpan demand kontinu dan biaya simpan demand diskrit.

\section{Biaya simpan demand kontinu}

$$
\begin{aligned}
& =\frac{1}{2} t_{1} Q_{c} \\
& =\frac{1}{2}\left(\frac{T D}{P}\right)\left(T D_{c}\right) \\
& \quad=\frac{1}{2 P} T^{2} \cdot D \cdot D_{C}
\end{aligned}
$$

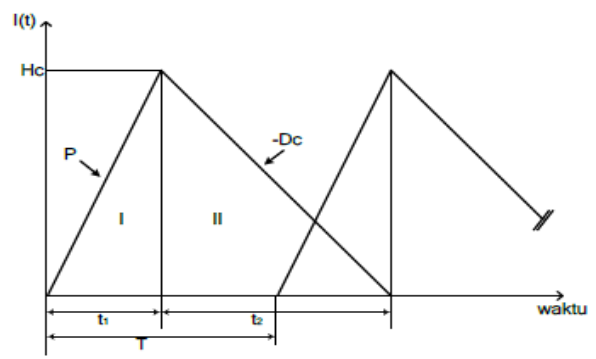

Gambar 2. Persediaan Produk untuk memenuhi Demand Kontinu pada Model EPQ dengan Dua Tipe Demand[23]

Persediaan rata-rata bagian I:

$$
\begin{gathered}
=\frac{1}{2} t_{1} Q_{c} \\
=\frac{1}{2}\left(\frac{T D}{P}\right)\left(T D_{c}\right)
\end{gathered}
$$$$
=\frac{1}{2 P} T^{2} \cdot D \cdot D_{C}
$$

Persediaan rata-rata bagian II:

$$
\begin{aligned}
= & \frac{1}{2} t \quad Q_{c} \\
= & \frac{1}{2}\left(T . T D_{c}\right)
\end{aligned}
$$

$=\frac{1}{2} T^{2} \cdot D_{c}$
Dengan biaya simpan per unit waktu adalah $h$ maka, biaya simpan demand kontinu dalam satu siklus adalah:
B. simpandemandkontinupersiklus $=$
h. $[(12 P . T 2 . D)+.(12 . T 2)$.

\section{Biaya simpan demand diskrit}

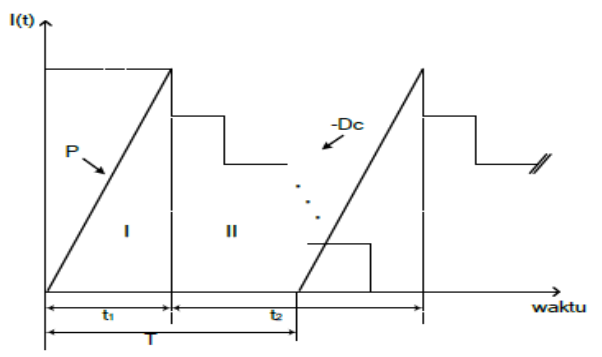

Gambar 3. Persediaan Produk untuk memenuhi Demand Diskrit pada Model EPQ dengan Dua Tipe Demand [23]

Persediaan rata-rata bagian I:

$$
\begin{aligned}
& =\frac{1}{2} t_{1} Q_{D} \\
= & \frac{1}{2}\left(\frac{T D}{P}\right)\left(T D_{D}\right)
\end{aligned}
$$

$$
=\frac{1}{2 P} T^{2} \cdot D \cdot D_{D}
$$

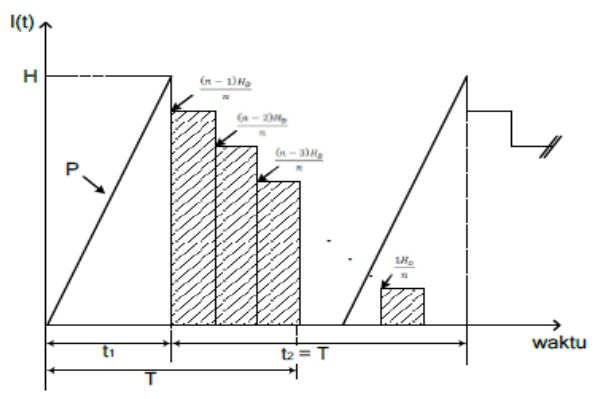

Gambar 4. Persediaan Produk Demand Diskrit selama $t 2$ pada Model EPQ dengan Dua Tipe Demand [23]

Pada bagian II, produk dikirim $n$ kali setiap rentang waktu $T / n$ dengan jumlah total produk yang dikirim adalah sebanyak persediaan maksimum $H D=Q D$. Gambar 4. memperlihatkan persediaan selama $t 2$ untuk memenuhi demand diskrit.

Persediaan rata-rata bagian II: 
$=\left(\frac{(n-1) H_{D}}{n} \frac{T}{n}\right)+\left(\frac{(n-2) H_{D}}{n} \cdot \frac{T}{n}\right)+\left(\frac{(n-3) H_{D}}{n} \cdot \frac{T}{n}\right)+\ldots+\left(\frac{1 H_{D}}{n} \cdot \frac{T}{n}\right)$

$=\frac{H_{D} T}{n^{2}}[(n-1)+(n-2)+(n-3)+\ldots+1]$

$=\frac{H_{D} T}{n^{2}} \cdot \frac{n(n-1)}{2}$

$=\frac{(n-1) \cdot H_{D} T}{2 n}$

dengan mempertimbangkan bahwa $\mathrm{Hd}=\mathrm{Qd}$, maka diperoleh persediaan rata-rata bagian II adalah:

$$
\begin{aligned}
& =\left(\frac{n-1}{2 n}\right) T \cdot Q_{D} \\
& =\left(\frac{n-1}{2 n}\right) T \cdot\left(T \cdot D_{D}\right) \\
& =\left(\frac{n-1}{2 n}\right) T \cdot{ }^{2} D_{D}
\end{aligned}
$$

Maka, biaya simpan demand diskrit dalam satu siklus adalah:

\section{B. simpandemanddiskritpersiklus}

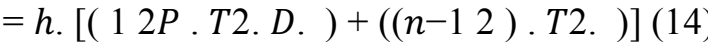

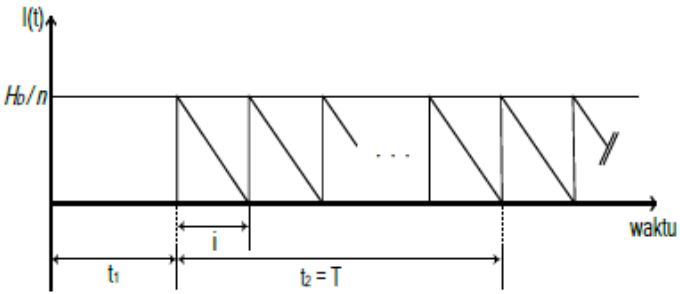

Gambar 5. Persediaan Produk Demand Diskrit yang disimpan oleh Konsumen selama $t 2$ pada Model EPQ dengan Dua Tipe Demand[23]

Selain biaya simpan di gudang pabrik, model EPQ ini mempertimbangkan biaya simpan per unit produk yang ditanggung oleh konsumen. Ketika produk diterima oleh konsumen sebanyak HD/n, konsumsi produk tidak dilakukan sekaligus hingga stok habis, melainkan secara bertahap. Hal ini mengakibatkan adanya biaya simpan yang harus dikeluarkan oleh konsumen.

Demand diskrit $H D$ dikirimkan $n$ kali dalam satu siklus dan dalam rentang waktu yang tetap $i$, sehingga

$i=\frac{T}{n}$

Berdasarkan Gambar 5. jumlah persediaan setiap pengiriaman adalah

$$
=\frac{1}{2} \cdot \frac{H_{D}}{n} \cdot \frac{T}{n}
$$

dengan frekuensi pengiriman per siklus sebanyak $n$ maka jumlah persediaan dalam satu siklus akan menjadi

$$
\begin{aligned}
& =\left(\frac{1}{2} \cdot \frac{H_{D}}{n} \cdot \frac{T}{n}\right) n \\
& =\frac{H_{D} T}{2 n}
\end{aligned}
$$

Substitusikan persamaan (7), sehingga diperoleh jumlah persediaan dalam satu siklus menjadi

$$
=\frac{T^{2} \cdot D_{D}}{2 n}
$$

Maka, biaya simpan demand diskrit yang disimpan oleh konsumendalam satu siklus adalah $B$. simpanolehkonsumenpersiklus

$$
=h 1 . T 2 . D D 2 n
$$

\section{Fungsi Tujuan}

Total biaya per siklus $T C(T, n)$ terdiri dari biaya produksi, biaya set up mesin, biaya simpan produk, baik oleh produsen maupun konsumen, serta biaya tetap dan variabel pengiriman. Maka, TC $(T, n)$ adalah penjumlahan dari persamaan (1), (3), (4), (11), (14), dan (19) sehingga :

$$
\begin{aligned}
& T C(T, n)=c_{p} T D+c_{s}+\left(n c_{f}+c_{d} T D\right) \\
& +\left(\frac{h T^{2} D D_{C}}{2 P}+\frac{h T^{2} D_{C}}{2}\right)+\left[\frac{h T^{2} D D_{D}}{2 P}+\frac{(n-1) T^{2} D_{D}}{2 n}\right] \\
& +\frac{h_{1} T^{2} D_{D}}{2 n}
\end{aligned}
$$

Fungsi tujuan yang ingin dicari adalah biaya rata-rata satu periode $E[T C U(T, n)]$, yang merupakan hasil pembagian dari total biaya per siklus dibagi dengan panjang waktu siklus. Maka, biaya rata-rata satu periode produksi $E[T C U(T, n)]$ dapat dirumuskan menjadi

$$
\begin{aligned}
E[T C U(T)]= & \frac{E[T C(T, n)]}{T} \\
= & c_{p} D+\frac{c_{s}}{T}+n \frac{c_{f}}{T}+c_{d} D+\frac{h T D}{2 P}\left(D_{C}+\right. \\
& \left.D_{D}\right)+\frac{h T}{2}\left(D_{C}+D_{D}\right)+\frac{T D_{D}}{2 n}\left(h_{1}-h\right)
\end{aligned}
$$

\section{Prosedur Solusi Optimal}

Panjang waktu siklus optimal dapat diperoleh dengan meminimalkan $[(T)]$. Dilakukan diferensiasi $E[T C U(T)]$ terhadap $T$ sehingga memberikan hasil turunan sebagai berikut : 
Tabel 2. Hasil diferensiasi $E[T C U(T)]$ terhadap $T$

\begin{tabular}{|c|c|c|c|c|c|c|c|c|}
\hline \multirow{3}{*}{ Bulan } & \multicolumn{6}{|c|}{ Permintaan } & & \multirow[b]{3}{*}{ Produksi } \\
\hline & \multicolumn{2}{|c|}{$T$} & \multicolumn{3}{|c|}{$\mathbf{S}$} & \multicolumn{2}{|l|}{ B } & \\
\hline & 1 & 2 & 1 & 2 & 3 & 1 & $\begin{array}{l}\text { Permintaan } \\
\text { dan } \\
\text { Pengiriman }\end{array}$ & \\
\hline & & & & & 2015 & & & \\
\hline 1 & 5 & 5 & 10 & 5 & 10 & 10 & 100 & 120 \\
\hline 2 & 10 & 0 & 0 & 10 & 0 & 5 & & \\
\hline 3 & 5 & 5 & 5 & 10 & 10 & 0 & 50 & \\
\hline 4 & 10 & 10 & 5 & 0 & 0 & 5 & & \\
\hline 5 & 0 & 5 & 0 & 0 & 10 & 10 & 100 & 140 \\
\hline 6 & 5 & 5 & 5 & 10 & 5 & 0 & & \\
\hline 7 & 10 & 0 & 5 & 0 & 5 & 5 & & \\
\hline 8 & 0 & 10 & 0 & 0 & 5 & 5 & 50 & \\
\hline 9 & 5 & 5 & 5 & 5 & 5 & 5 & 100 & 150 \\
\hline 10 & 10 & 0 & 10 & 0 & 5 & 5 & & \\
\hline 11 & 0 & 5 & 0 & 0 & 5 & 5 & & \\
\hline 12 & 5 & 0 & 0 & 10 & 5 & 5 & & \\
\hline & & & & & 2016 & & & \\
\hline 1 & 10 & 5 & 10 & 0 & $\therefore$ & 5 & 100 & 100 \\
\hline 2 & 0 & 10 & 10 & 5 & $\therefore-$ & 0 & & \\
\hline 3 & 5 & 0 & 0 & 10 & $\therefore-$ & 5 & & \\
\hline 4 & 5 & 5 & 5 & 0 & $\because$ & 5 & & \\
\hline 5 & 10 & 5 & 5 & 0 & $\therefore$ & 5 & 100 & \\
\hline 6 & 0 & 10 & 0 & 0 & $\therefore$ & 5 & & 150 \\
\hline 7 & 5 & 5 & 5 & 5 & $\therefore-$ & 5 & & \\
\hline 8 & 10 & 0 & 10 & 5 & $\therefore-$ & 0 & & \\
\hline 9 & 5 & 0 & 5 & 0 & $\therefore$ & 5 & 100 & \\
\hline 10 & 0 & 5 & 5 & 10 & $\therefore-$ & 5 & & 120 \\
\hline 11 & 5 & 10 & 0 & 0 & $\therefore-$ & 0 & 50 & \\
\hline 12 & 5 & 5 & 5 & 10 & $\therefore$ & 5 & & \\
\hline & & & & & 2017 & & & \\
\hline 1 & 5 & 5 & 10 & 10 & $\therefore$ & $\therefore$ & 100 & \\
\hline 2 & 0 & 10 & 0 & 5 & $\therefore$ & $\therefore$ & & 120 \\
\hline 3 & 5 & 0 & 5 & 0 & $\therefore$ & $\because$ & & \\
\hline 4 & 0 & 10 & 0 & 10 & $\because$ & $\because$ & & \\
\hline
\end{tabular}

Tabel 3. Kebutuhan dan Harga Produksi

\begin{tabular}{lr}
\hline Kebutuhan & Harga produksi \\
\hline Tapioka & 6500 \\
\hline $\begin{array}{l}\text { Bumbu dan } \\
\text { perasa }\end{array}$ & 1500 \\
\hline Ikan & 20000 \\
\hline Lain-lain & 2000 \\
\hline Total & 274000 \\
\hline
\end{tabular}

Panjang waktu siklus optimal dapat diperoleh dengan meminimalkan $E[T C U(T)]$. Panjang waktu siklus optimal dapat dirumuskan sebagai berikut :

$$
T=\sqrt{\frac{2\left(C_{S}+n C_{f}\right)}{\frac{h D^{2}}{P}+h D+\frac{D_{D}\left(h_{1}-h\right)}{n}}}
$$

Produksi UD Sanda adalah $4 \mathrm{~kg} /$ jam dan produk ini diproduksi untuk memenuhi demand total sebanyak $335 \mathrm{~kg}$ per tahun. Produksi kerupuk menyesuaikan ketersediaan ikan di sungai pasca banjir. Biasanya per tiga bulan produksi dengan jumlah produksi ratarata per periode adalah $137 \mathrm{~kg}$. Jumlah pengiriman kontinyu adalah sebayak 3 (tiga) kali. Persentase demand kontinu dan diskrit masing-masing adalah $60 \%$ dan $40 \%$. Jumlah jam kerja dalam 1 hari adalah $+/-6$ jam dan jumlah hari kerja per tahun adalah 360 hari per tahun. Parameter lain yang dipertimbangkan dalam contoh ini adalah sebagai berikut: biaya setup mesin $(c s)=\mathrm{Rp} .100 .000$; biaya produksi $(c p)=\mathrm{Rp} 30.000$ per kg;biaya pengiriman tetap $(c f)=$ Rp. 500.000 per pengiriman; biaya pengiriman variabel $(c d)=$ Rp. 3.000 per unit; biayasimpan $(h)=$ Rp. 1000 per unit; dan biaya simpan ditanggung konsumen $(\mathrm{h} 1)=\mathrm{Rp} .1500$ per unit. Diasumsikan bahwa pengiriman demand diskrit $n=2$. Berdasarkan perhitungan dengan menggunakan Persamaan (23) diperoleh bahwa waktu siklus optimal pengiriman kerupuk ke agen adalah $T^{*}=2 \mathrm{kali}$, total cost TC (persamaan 20) adalah Rp. $6.673 .500,-$ dan biaya rata-rata produksi kerupuk dalam satu periode $E[T C U(T)]$ persamaan (21)adalah Rp. 3.336.750,-

\section{KESIMPULAN}

Penelitian ini mencari solusi optimal dari metode Economic Production Quantity (EPQ) dengan mempertimbangkan dua tipe demand kontinu dan diskrit secara simultan. Formulasi model yang digunakan adalah model matematis dengan demand diskrit dan kontinyu. Berdasarkan perhitungan diperoleh bahwa waktu siklus optimal pengiriman ke agenselama2 kali (awalnya waktu siklus 3 kali setahun) dan biaya produksi rata-rata satu periode adalah Rp. 3.336.750,-. Dengan besarnya biaya Total adalah Rp. 6.673.500,- / tahun. 
DAFTAR PUSTAKA

[1] Absi, N., Detienne, B., Auzere-Peres, S. (2012). Heuristics For The Multi-Item Capacitated Lot-Sizing Problem With Lost Sales. Computer \& Operation Research. 40, $264-272$

[2] Afrizal Nilwan, Yunita Sofyandy, Goenawan. (2011). Analisis Perhitungan Economic Order Quantity (EPQ) Dan Pengaruhnya Terhadap Pengendalian Persediaan Barang Dagangan., JURNAL Akuntansi \& Keuangan Volume 2, Nomor 2, September 2011

[3] Agus, Cipta, dan Yulianthini. (2015). Penerapan Economis (EPQ) dalam Pengelolaan Persediaan Bahan Baku Tepung pada Usaha Pia Ariawan di Desa Banyuning Tahun 2013., e-Journal Bisma Universitas Pendidikan Ganesha, Jurusan Manajemen. Vol.3.

[4] Arie Desrianty, Fifi Herni M, Adelia Septy Perdana. (2015). Model Optimisasi Ukuran Lot Produksi yang Mempertimbangkan Inspeksi Sampling dengan Kriteria Minimisasi Total Ongkos. 5th National Industrial Engineering Conference e-journal lib.itenas.ac.id/

[5] Arindum Mukhopadhyay and Adrijit Goswami. (2014). Economic Production Quantity (EPQ) Model For Three TypeImperfect Items With Rework And Learning In Setup. An International Journal of Optimizationand Control: Theories \& Applications Vol.4, No.1, pp.57-65 (2014)c IJOCTAISSN:21460957 eISSN:21465703DOI:10.11121/ijocta.01.2014.00170h ttp://www.ijocta.com

[6] Assauri, Sofjan. (2004). Manajemen Pemasaran. PT. Raja Grafindo

[7] Atul B. Borade, and Pankaj S. Ardak. (2017). A State Of Art On Economic Production Quantity Models. Brazilian Journal of Operations \& Production Management 14 (2017), pp 183-186 ABEPRO DOI: 10.14488/BJOPM.

2017.v14.n2.a5

[8] Azmi, Zahroh, dan Maria. (2016). Analisis Metode Economic Order Quantity (EPQ) sebagai Pengendalian Persediaan Bahan Baku Pembantu.Jurnal Administrasi Bisnis (JAB). Vol 33. No. 1 April 2016.

[9] Ballou, H. Ronald. (1992). Business Logistics Management. (Ed. 3). PrenticeHall, Inc : New Jersey
[10] Cahya Karuniawan.

(2015).

OPTIMALISASI

SISTEM

PERSEDIAAN BAHAN BAKU KAIN

MENGGUNAKAN METODE

ECONOMIC ORDER QUANTITY

(EPQ) (Studi Kasus pada : PT. New

Makmurtex). e-journal

http://eprints.dinus.ac.id/16918/1/jurnal 161

01.pdf

[11] Carien Valerie Sakkung. (2011). Perbandingan Metode EPQ (Economic Order Quantity) Dan Jit (Just In Time) Terhadap Efisiensi Biaya Persediaan Dan Kinerja Non-Keuangan (Studi Kasus Pada Pt Indoto Tirta Mulia). Akurat Jurnal Ilmiah Akuntansi Nomor 05 Tahun ke-2 Mei-Agustus 2011.

[12] De Castro, L. E., Tabucanon, T., Nagarur, N. N. (1995). A Production Order Quantity Model With Stochastic Demand for a Chocolate Milk Manufacturer. International Journal Production Economis. 49, 145 - 156

[13] Diah Nur Fadliilah, Hastarini Dwi Atmanti. (2012). ANALISIS PENYERAPAN TENAGA KERJA PADA INDUSTRI KECIL (Studi Kasus di Sentra Industri Kecil Ikan Asin di Kota Tegal). DIPONEGORO JOURNAL OF ECONOMICS Volume 1, Nomor 1, Tahun 2012, Halaman 1-13

[14] Endang Mulyana, Evi Febianti, dan Kulsum Kulsum. (2015). Analisis Jumlah Produksi Dan Total Cost Produksi Menggunakan Metode Economic Production Quantity (EPQ) dan Metode Economic Order Quantity(EPQ).

[15] Eynan. (2003). The Benefit of Flexible Production Rates in the Economic Lot Scheduling Problem. IIE Transaction. 35 (7), 1057-1064

[16] Gede Agus Darmawan, Wayan Cipta, Ni Nyoman Yulianthini. (2015). Penerapan Economic Order Quantity (EPQ) Dalam Pengelolaan Persediaan Bahan Baku Tepung Pada Usaha Pia Ariawan Di Desa Banyuning Tahun 2013. e-Journal Bisma Universitas Pendidikan Ganesha Jurusan Manajemen (Volume 3 Tahun 2015)

[17] Gema L dan Retno S. (2014). Analisis Pengendalian Persediaan Bahan Baku Daging Dan Ayam Dengan Menggunakan Metode Economic Order Quantity (EPQ) Pada Restoran Steak Ranjang Bandung. eProceeding of Management : Vol.1, No.3 Desember 2014 ISSN : 2355-9357 
[18] Indroprastio Erma. 2012. Analisis Pengendalian Persediaan Produk dengan Metode EPQ Menggunakan Algoritma Genetika untuk Mengefisiensikan Biaya persediaan. Jurnal Teknik ITS. Vol. 1. September 2012.

[19] Intan Maesti Gani dan Marheni Eka Saputri. (2015). Analisis Peramalan Dan Pengendalian Persediaan Bahan Baku Dengan Metode EPQ pada Optimalisasi Kayu Di Perusahaan Purezento. eProceeding of Management : Vol.2, No.2 Agustus 2015 | Page 2029.

[20] Muhammad Ryan Wirakusuma, Arie Desrianty, Hendro Prassetiyo. (2016). Model Optimisasi Ukuran Lot Produksi Pada Sistem Produksi Tidak Sempurna Dengan Mempertimbangkan Pemeriksaan Sampling Berganda Dan Proses Rework. Reka Integra ISSN: 2338-5081.

[21] Mutiara Simbar, Theodora M.Katiandagho Tommy F. Lolowang, dan Jenny Baroleh. (2014). Analisis pengendalian persediaan bahan baku kayu cempaka pada industri mebel dengan menggunakan metode EPQ (studi kasus pada ud. Batu zaman). Jurnal Ilmiah, oktober 2014.

[22]Nikken Prima Puspita, Siti Khabibah, dan Lucia Ratnasari. (2014). Model Optimasi Economic Production Quantity Dengan Sistem Delivery Order. Jurnal Matematika Vol 17, No. 2, Agustus 2014 : 50-54.

[23] Nurike.O., Henmaidi. dan Johnrinaldi. (2016). Pengembangan Model Economic Produkscion Quantity (EPQ) dengan sinkronisasi demand diskrit dan demand Kontinyu secara simultan., Jurnal Optimasi Sistem Industri, Vol. 15 No. 1, April 2016:78-86

[24] Parwita Setya Wardhani. (2015). Perencanaan Dan Pengendalian Persediaan Dengan Metode EPQ. Media Mahardhika Vol. 13 No. 3 Mei 2015.

[25] Perdana., Adelia. (2008). Model Optimasi Ukuran Lot Produksi yang Mempertimbangkan Inspeksi Sampling untuk Meminimasikan Total Biaya. Jurnal Online. Jurusan Teknik Industri. ITENAS. Bandung.

[26] Rangkuti., Freddy. (2004). Manajemen Persediaan: Aplikasidi Bidang Bisnis. Grafindo Persada, Jakarta

[27] Rommy Hudallah Ramadlan, Hendro Prassetiyo, Arie Desrianty. (2015). Model optimisasi ukuran lot produksi pada sistem produksi yang mengalami deteriorasi dan mempertimbangkan Inspeksi sampling dengan kriteria minimisasi total ongkos. Reka Integra ISSN: 2338-5081 Jurusan Teknik Industri Itenas | No.04 | Vol.03 Oktober 2015

[28] Sheila Giltania Kaluntas Noortje, M. Benu Yolanda P. I. Rori. (2016). Analisis Persediaan Bahan Baku Pada Usaha Kecil Menengah Produk Roti (Studi Kasus Ud Nabila Desa Kalasey, Kecamatan Mandolang). Agri-Sosioekonomi Volume 12 Nomor 2, Mei 2016 : 95-104.

[29] Siti Nurhasanah. (2012). Analisis Persediaan Solar Dengan Menggunakan Metode Economic Order Quantity (EPQ) pada PT Anugerah Bara Kaltim. JURNAL EKSIS Vol.8 No.2, Agustus 2012: 2168 2357

[30] Tesalonika M. Lantang. (2013). Penerapan metode penilaian persediaan bahan baku pada pt. Cargill indonesia copra crushing plant amurang.

[31] Winarti Setyorini, Siti Khotimah, Lili Herlina. (2015). Analisis Persediaan Barang Dagang Beras pada Toko H.S.A Putra Pangkalan Bun. Juristek, Vol 4 No. 1, Juli 2015, Hal 34 - 56.

[32] Wuri, Josephine dan Yuliana Rini Hardanti. (2006). Peranan Industri Kecil Dalam Meningkatkan Pendapatan Masyarakat : Studi Kasus Pada Industri Kerajinan Batik Kayu di Dusun Krebet, Sendangsari, Pajangan, Bantul. KINERJA, Volume 10, No.2, Tahun. 2006. Universitas Sanata Dharma Yogyakarta.

[33] Yamit. Zulian. (2010). Manajemen Kualitas Produk dan Jasa. Ekonesia. Yogyakarta

[34] Yulius Gessong Sampeallo. (2012). Analisis pengendalian persediaan pada ud. Bintang furniture sangasanga. JURNAL EKSIS Vol.8 No.1, Mar 2012: 2001 2181 